\title{
The Direct and Indirect Factors on Affecting Organizational Sustainability
}

\author{
Meng-Shan Tsai ${ }^{1,2}$, Meng-Chen Tsai ${ }^{1} \&$ Chi-Cheng Chang ${ }^{1}$ \\ ${ }^{1}$ Department of Technology Application and Human Resource Development, National Taiwan Normal \\ University, Taipei, Taiwan \\ ${ }^{2}$ Graduate Institute of Human Resource and Knowledge Management, National Kaohsiung Normal University, \\ Kaohsiung, Taiwan \\ Correspondence: Meng-Chen Tsai, Department of Technology Application and Human Resource Development, \\ National Taiwan Normal University, 162, HePing East Road Section 1, Taipei, Taiwan. Tel: 886-02-7734-3439. \\ E-mail: supercarydbt@yahoo.com.tw
}

Received: April 16, 2013

Accepted: May 10, $2013 \quad$ Online Published: November 18, 2013

doi:10.5539/jms.v3n4p67

URL: http://dx.doi.org/10.5539/jms.v3n4p67

\begin{abstract}
Successful firms pursue organizational sustainability. The aim of this study is to explore the direct and indirect factors affecting on organizational sustainability. Indirect factors being those that first influence competitive advantage, and then affecting organizational sustainability. This study analyzes 145 articles retrieved from the SDOL (Science Driect Online) database that were published between 2009 and January 2013. Papers were retrieved using 'organizational sustainability' and 'competitive advantage' as keywords, searching on 'Abstract, Title, Keywords', and subject headings of 'Business, Management and Accounting'. The results identify that 13 indirect factors and 3 direct factors can have an impact on organizational sustainability.
\end{abstract}

Keywords: competitive advantage, organizational sustainability

\section{Identification of Studies}

This study examines two sets of factorSs that affect organizational sustainability, direct and indirect. Direct factors influence organizational sustainability, and so 'organizational sustainability' was taken as a keyword, searching on 'Abstract, Title, Keywords', in addition to the subject headings of 'Business, Management and Accounting'. Four articles published between 2009 and January 2013 were retrieved from the SDOL (Science Driect Online) database. Indirect factors influence organizational sustainability through competitive advantage, and again 'competitive advantage' was taken as a keyword to search on 'Abstract, Title, Keywords', in addition to the same subject headings. A total of 364 articles were retrieved from SDOL, of which 145 published between 2009 and January 2013 were used.

\section{Definitions}

\subsection{Sustainability}

Sustainability has become a significant issue in the popular press, corporate boardrooms, political arenas and academia. The United Nation's 1989 Brundtland Commission definition of sustainability is "meeting the needs of the present without compromising the needs of future generations" and According to the OECD's definition, sustainability means"linking the economic, social and environmental objectives of societies in a balanced way" and "about the consequences of today's activities which meet the challenge of sustainable development and require that the process through which decisions are reached is informed by the full range of possible consequences, and is accountable to the public" (Farneti \& Guthrie, 2009; Mohrman \& Worley, 2010). Sustainability shows both challenges and opportunities for organizations (Ceasar \& Page, 2013), and it can overcome economic pressures and fit the future needs of the environment (Wilkinson \& Hill, 2001). The activists of sustainable development which claims that as progress, but others may consider the level of progress as inadequate to meet sustainable development needs and seek more dramatic change (Henderson, 2011).

There are six aspects to sustainability:

a) Causal ambiguity: Rival firms may not be able to imitate another firm's resources and capabilities because 
they do not understand how these relate to competitive advantage.

b) Lead time: A set of factors that determine the amount of time from project launch until competitors have a substantive response in place.

c) Path dependency: The choices made during the early stages of project planning and implementation that have significant implications on current options, decisions and expected outcomes.

d) Role of history: Refers to unique historical conditions that allow a company to either acquire or develop resources at low cost. New competitors who do not have these resources will have to pay a higher price in order to obtain them.

e) Socially complex links: Social factors, which are beyond the ability of firms to control and influence in a systematic fashion, that make it difficult to imitate another firm's resources.

f) Time compression diseconomies: Refers to resources that are relatively easy or inexpensive to imitate, but where the process is time-consuming (Dehning \& Stratopoulos, 2003).

\subsection{Competitive Advantage}

Competitive advantage is an important concept in strategic practice and necessary for a firm (Baaij, Greeven, \& Dalen, 2004; Tollin \& Jones, 2007). The strategic of competitive advantage is based on the enterprise's scope of competence and real means (Passemard \& Kleiner, 2000). The organization has competitive advantage and can use it to change environment (Appelbaum \& Gallagher, 2000). The notion of competitive advantage illustrates a private sector view that looks to maximize profits by outperforming competitors, as opposed to the public sector where non-profit objectives are more often the goal (Henderson, 2011). Strong competitive advantage is a goal of many organizations, which they are determined to maintain (Chang \& Liu, 2009). Competitive advantage of an organization or enterprise means the value a form (Byrd \& Turner, 2001). A firm establishes competitive advantage through its business strategy with regards to markets and developing capability (Griffiths \& Finlay, 2004), and uses this advantage to enhance the value of its products and services (Chuang, 2004; Reed, Lemak, \& Mero, 2000).

Competitive advantage has two perspectives: industrial organization economics and the resource-based view of the firm. Industrial organization economics shows how sustainable competitive advantage is based on the firm's strategic positioning within an industry. The resource-based view of the firm bases competitive advantage on economizing on the firm's core competencies. These core competencies, which are valuable, unique and difficult to imitate, trade or replace, are fundamental to sustainable competitive advantage (Baaij et al., 2004).

\subsection{Competitive Advantage-Sustainability}

The concept of sustainable development involves economic, social and environmental factors and has emerged as central to the thinking of any individual or organization with an eye for global economic development (Henderson, 2011; Rodriguez, Ricart, \& Sanchez, 2002). In addition, the overall competitive advantage of a firm can actually be influenced by environmental factors (Wagner, 2005). This study considers what factors affect competitive advantage and sustainability and constructs a model of the relationship between competitive advantage and sustainability.

Companies must develop new resources, capabilities and activities to maintain their competitive advantages, and competitive advantages will provide firm with a generic view of a sustainable business for a firm (Rodriguez et al., 2002). A sustainability competency provides a differential advantage; this competency is relatively unique in the firm's market (Flint, \& Golicic, 2009). The sustainable development can be achieved within the context of competitive advantage. Sustainability development will be more quickly achieved if an organization can adopt the sustainable event as a competitive tool in the market (Henderson, 2011).

\section{Areas of Emphasis in Organizational Sustainability Research}

Following a review of the research literature, related concepts were identified and the framework shown in Figure 1 was developed. This framework arranges organizational sustainability research according to several areas of emphasis containing direct and indirect factors that affect organizational sustainability. 


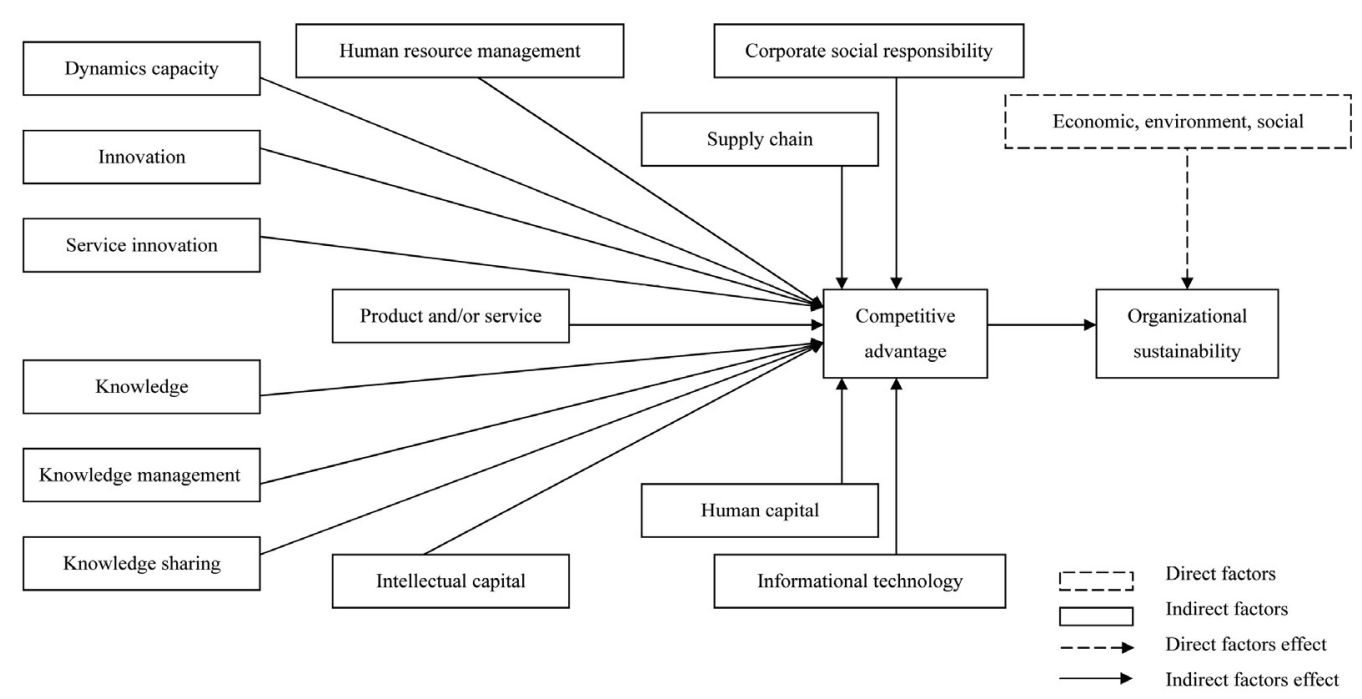

Figure 1. Direct and indirect factors to organizational sustainability

\subsection{Direct Factors Affecting Organizational Sustainability}

A sustainable business depends on economics, especially the economics of sustainability (Guest, 2010), and Islam and Clarke (2005) demonstrate that sustainability is often associated with economics and aims at economic growth. Sharma and Ruud (2003) indicate that corporate social and environmental performance develops sustainability metrics. Social performance aims at development and expansion through multi-stakeholder and cross-cultural collaborations between companies, governments, communities and non-governmental organizations (NGOs). Environmental performance includes developing environmental strategies to describe the external and internal drivers behind the environmental practices adopted by the organization and how those environmental practices are assessed, and to monitor the connection between environmental practice and profitability. Moreover, the purpose of corporate sustainability is to improve the economical, environmental and social performance of companies (Bos-Brouwers, 2010), and these three aspects all act as indicators in the assessment of sustainability therefore. Each indicator can assess the direction of development, in line with a sustainable development path (Garnåsjordet, Aslaksen, Giampietro, Funtowicz, \& Ericson, 2012). Sustainability is associated with emotional demands, through social and environmental requirements, as well as with rational demands, from the economic viewpoint of the business (Gupta, Czinkota, \& Melewar, in press)

\subsection{Indirect Factors Affecting Organizational Sustainability}

The previous section explains the influence of competitive advantage on organizational sustainability, and this section discusses the indirect factors that influence organizational sustainability, that is, the constructs that influence competitive advantage. The number of articles that explain the relationship between these factors and competitive advantage are shown in Table 1.

Table 1. Numbers of articles of constructs towards competitive advantage from 2009 to 2013

\begin{tabular}{ll}
\hline Constructs & Numbers of articles (From 2009 to 2013) \\
\hline Dynamics capability & 4 \\
Innovation & 9 \\
Service innovation & 4 \\
Knowledge & 11 \\
Knowledge management(KM) & 9 \\
Knowledge sharing (KS) & 3 \\
Human resource management (HRM) & 4 \\
Product and/or service & 5 \\
Human capital & 3 \\
Intellectual capital & 3 \\
Corporate social responsibility (CSR) & 4 \\
Supply chain & 6 \\
Informational technology (IT) & 8 \\
\hline
\end{tabular}


In fact, many factors that influence competitive advantage have been identified, but several have only been discussed in one paper. Therefore, the factors included in Table 1 are those that have been discussed in three or more papers between 2009 and January 2013, as retrieved from the SDOL database.

\subsubsection{Dynamic Capability}

Dynamic capability can be defined as 'the capability of an organization to purposely create, extend, or revise its resource base' (Chen \& Fong, 2012). It is the main source of competitive advantage for firms which can integrate, learn, build and reconfigure their internal and external resources to adapt to changes in the business environment and sustain that advantage (Gebauer, 2011; Li \& Liu, in press; Wu, 2010).

\subsubsection{Innovation}

Innovation can create, support and maintain competitive advantage (Rios-Morales \& Brennan, 2009). Therefore, innovation is regarded as a key element in entrepreneurship as well as a source of competitive advantage (Tan, Shao, \& Li, 2013). Organizational innovation can improve a firm's performance, but the organization needs to accumulate knowledge in order to achieve innovation. Consequently, knowledge positively affects a firm's capability to be innovative (Ganter \& Hecker, in press).

\subsubsection{Service Innovation}

Service innovation comprises service concept, processes and systems. The three concepts are based on using knowledge acquired to meet customer needs. Thus, service innovation refers to a firm incorporating new knowledge into a better service offer (Salunke, Weerawardena, \& McColl-Kennedy, 2011). Hence, service innovation can sustain competitive advantage (Heracleous \& Wirtz, 2009; Salunke et al., 2011; Salunke, Weerawardena, \& McColl-Kennedy, in press).

\subsubsection{Knowledge}

Knowledge is created and remembered by individuals, and a company uses that knowledge in the production process of goods and services (Dai \& Liu, 2009). Therefore, knowledge is important to an organization; as previously stated, it is knowledge that creates, supports and sustains a competitive advantage (Erickson \& Rothberg, 2009; Huang, Fan, Chern, \& Yen, 2013; Javalgi, Dixit, \& Scherer, 2009; Lin \& Wu, 2010; Powell \& Ambrosini, 2012).

\subsubsection{Knowledge Management (KM)}

$\mathrm{KM}$ refers to a systematic and integrative process of documenting and disseminating knowledge resources throughout an organization, in order to coordinate the pursuit of organizational goals (Zheng, Yang, \& McLean, 2010). KM is essential to organizations, due to its potential to achieve, develop, maintain and enhance competitive advantage (Matzler \& Mueller, 2011; Tseng, 2012; Zheng et al., 2010). Thus, KM is an enabler for organizational success (Matzler \& Mueller, 2011).

\subsubsection{Knowledge Sharing (KS)}

$\mathrm{KS}$ is a core process of KM. It means making knowledge available to other people within an organization, so that people obtain task information, know-how and feedback with regards to a product or procedure. Effective KS can facilitate organizational learning and innovation, because, before combining existing and new knowledge, relevant knowledge must first be acquired and then incorporated into the existing knowledge base (Matzler \& Mueller, 2011). Therefore, KS is a critical process in creating a competitive advantage (Matzler \& Mueller, 2011; Montazemi, Pittaway, Saremi, \& Wei, 2012; Powell \& Ambrosini, 2012).

\subsubsection{Human Resource Management (HRM)}

Four studies were found that explained the relationship between human resources (HR) and competitive advantage, and HR involves strategic HRM and HRM systems (HRMS).

HRM implies that HR managers should attempt to enhance an organization's competitive advantage. At the core of strategic HRM is the pre-eminence of human capital in business strategy and competition (Munyon, Summers, \& Ferris, 2011). HRMS is the sum of the HRM policies and practices of a company, which are horizontally and vertically aligned for the purpose of attracting, developing and retaining that company's human resources. Horizontal alignment refers to practices being integrated; vertical alignment refers to those practices that are associated with internal and contextual factors (e.g., organizational strategy, culture) (Festing \& Eidems, 2011). HRM is a critical support activity that, when combined with other value chain activities, is key to a company achieving and maintaining a competitive advantage (Buller \& McEvoy, 2012; Calabrese, Costa, \& Menichini, in press). 


\subsubsection{Product and/or Service}

Service is a process that involves many activities which take place in the interaction between customers and providers, goods and other physical resources, as well as systems and infrastructures representing the service provider and involving other customers in order to resolve customers' problems (Kohtamäki, Partanen, \& Möller, 2013). Successful new product development (NPD) is a key driver for sustainable competitive advantage (Mu, Peng, \& MacLachlan, 2009). The uncertainty in the NPD process is a result of changes in customers' needs, competition and technology, but successful NPD can generate vast profits and a strong competitive advantage (Wei \& Chang, 2011).

\subsubsection{Human Capital (HC)}

$\mathrm{HC}$ refers to the knowledge which employees take with them, and comprises not only knowledge, but also skills, experiences and abilities that is individually and collectively held within the firm's human resources (Beattie \& Smith, 2010; Buller \& McEvoy, 2012). HC is regarded as the key source of competitive advantage for companies (Bowman \& Tomes, 2010). Family businesses also focus on HC, because their HC is most likely to be an important factor in maintaining their competitive advantage, and the $\mathrm{HC}$ of family members is more unique and complex than that of non-family members (Dawson, 2012).

\subsubsection{Intellectual Capital (IC)}

IC refers to those knowledge resources in the form of either employees, customers, processes or technology that the firm can mobilize in its value creation process. Moreover, IC has become a critical concept for evaluating a company's worth. As the business environment becomes a more knowledge-based economy, the importance of IC is increasing (Wu, Chen, \& Chen, 2010), and it is vital for companies facing an intensely competitive environment to increase their value by managing IC. Therefore, IC management is treated as a fundamental factor for sustaining a competitive advantage in today's business markets (Calabrese et al., in press; Lu, Wang, Tung, \& Lin, 2010).

\subsubsection{Corporate Social Responsibility (CSR)}

CSR refers to a company's commitment to developing a sustainable economy and working with employees, their families, the local community and society as a whole to improve the quality of life (Tsai, Hsu, Chen, Lin, \& Chen, 2010). CSR is a voluntary contribution by business to environmental, social and economic development (Garay \& Font, 2012). Companies now accept the conjunction of economic and social goals based on CSR, and that CSR is a source of opportunity, innovation and competitive advantage (Perry \& Towers, 2009). Hence, CSR can improve competitive advantage.

\subsubsection{Supply Chain}

Due to the relationship between markets and sources, demand and supply has enhanced the strategic relevance of supply chain management (SCM). It has become important for every company in today's competitive world to sustain an efficient and flexible supply chain (Büyüközkan \& Berkol, 2011), and firms build collaborative relationships with their supply chain partners to achieve this and maintain a competitive advantage (Nyaga, Whipple, \& Lynch, 2010). In fact, several studies, such as Ngai, Chau, and Chan (2011) and Nyaga et al. (2010), indicate that supply chain management or collaboration with supply chain partners improves the competitive advantage of companies.

\subsubsection{Information Technology (IT)}

Eight studies, published between 2009 and January 2013, were identified that help understand the relationship between IT and competitive advantage.

The continual advances in IT have created new opportunities for companies to obtain a competitive advantage, via operational effectiveness and/or strategic positioning. Reducing operational costs and having better technology, people, processes, input and management can achieve operational effectiveness. Strategic positioning can be achieved by delivering improved value to customers, which competitors cannot match (Phan \& Vogel, 2010). IT can improve performance and be integrated into business operations so that a competitive advantage is created (Chun \& Mooney, 2009; Masli, Richardson, Sanchez, \& Smith, 2011).

\section{Practical Implications of Organizational Sustainability Research}

Several practical implications for competitive advantage and organizational sustainability can be drawn from this and previous studies. First, according to Figure 1, an organization itself has an indirect effect on its own organizational sustainability through its competitive advantage. The reason for this is that sustainable development is based on competitiveness, and a business may develop new activities and capabilities that 
generate and maintain a competitive advantage (Mariadoss, Tansuhaj, \& Mouri, 2011). Second, as demonstrated by Mohrman and Worley (2010), economic, environmental and social elements, which are part of a company's external environment, have a direct effect on organizational sustainability. Sustainability means meeting the demands of the present generation without compromising the ability of future generations to satisfy their own needs, and one response to these economic, environmental and social challenges is government intervention (Kuckertz \& Wagner, 2010). Third, the results of this study show that knowledge is one of the most important indirect factors influencing organizational sustainability. Knowledge is the key source of competitive advantage, according to the resource-based view (Erickson \& Rothberg, 2009; Javalgi et al., 2009). In addition, heterogeneous knowledge among companies is the critical factor for sustained competitive advantage and superior corporate performance (Dai \& Liu, 2009). Thus, firms should build a system to encourage their employees to create, manage and share new knowledge, and use them to develop new services and products. Another important element in entrepreneurship and competitive advantage is innovation (Tan et al., 2013), and the innovation-oriented firms apply this capability to achieve a competitive advantage (Lew \& Sinkovics, 2012). Innovation should aim to develop services and products that are unique and difficult to imitate in order to maintain a competitive advantage (Li \& Tsai, 2009; Watjatrakul, 2005) and prevent other firms becoming new competitors. Those firms that develop several such services or products not only have a competitive advantage, but also have more opportunities for sustainability.

Fourth, an organization should develop core capabilities, which can be used to create or maintain its competitive advantage. Once an organization holds the monopoly in the market or becomes a member of an oligopolistic market, it is less likely to be an organization that can be replicated, and so has the opportunity to maintain its competitive advantage (Watjatrakul, 2005) and its organizational sustainability.

\section{Conclusion}

Based on the findings of this study, it is posited that the constructs of an organization or firm cannot help to achieve sustainability directly, but external factors can do so. Therefore, an organization or firm should try to apply its competencies or capabilities to creating or maintaining a competitive advantage, in order to obtain sustainability.

This study collected research papers published between 2009 and January 2013 from the SDOL database and listed and explained the factors that influence competitive advantage, and their interrelationships, which were discussed in three or more of those papers. Nevertheless, several factors are an important influence on competitive advantage, although they were studied only one or two times during the same period, such as organizational culture (Dawson, 2012), brand management (Santos-Vijande, Río-Lanza, Suárez-Álvarez, \& Díaz-Martín, 2013), customer relationship management (CRM) (Phan \& Vogel, 2010), and technology systems (Chen \& Chen, 2009), and so on. The reason is that an organizational culture influences employees, organizations and marketing management (Lund, 2003). Organizational culture has been examined with performance and effectiveness of a firm (Lee \& Yu, 2004), brand management satisfies the demands of firm's goal accomplishing (Beverland, 2005), CRM can create the value and satisfy buyer and seller, as well as achieve organizational financial performance (Lambert, 2010; Hoots, 2005) and technology systems generate business value and refer to the organizational performance (Morabito, Themistocleous, \& Serrano, 2009). Other sources of competitive advantage include cost advantage and differentiation (Mariadoss, Tansuhaj, \& Mouri, 2011), supplier issues (Guneri, Yucel, \& Ayyildiz, 2009), outsouring (Lee, 2009).

This study focuses on those factors that affect competitive advantage, and subsequently influence organizational sustainability, that is the factors that have an indirect effect on organizational sustainability. In future research, the authors of this study intend to use empirical research to examine the direct relationships between these factors and organizational sustainability.

\section{References}

Appelbaum, S. H., \& Gallagher, J. (2000). The competitive advantage of organizational learning. Journal of Workplace Learning, 12(2), 40-56. http://dx.doi.org/10.1108/13665620010316000

Baaij, M., Greeven, M., \& Dalen, J. V. (2004). Persistent superior economic performance, sustainable competitive advantage, and schumpeterian innovation: Leading Established Computer Firms, 1954-2000. European Management Journal, 22(5), 517-531. http://dx.doi.org/10.1016/j.emj.2004.09.010

Beattie, V., \& Smith, S. J. (2010). Human capital, value creation and disclosure. Journal of Human Resource Costing \& Accounting, 14(4), 262-285. http://dx.doi.org/10.1108/14013381011105957

Beverland, M. (2005). Brand management and the challenge of authenticity. Journal of Product \& Brand 
Management, 14(7), 460-461. http://dx.doi.org/10.1108/10610420510633413

Bos-Brouwers, H. E. J. (2010). Corporate sustainability and innovation in SMEs: Evidence of themes and activities in practice. Business Strategy and the Environment, 19(7), 417-435. http://dx.doi.org/10.1002/bse.652

Bowman, C., \& Tomes, S. (2010). Accounting for competitive advantage: The resource-based view of the firm and the labour theory of value. Critical Perspectives on Accounting, 21(3), 183-194. http://dx.doi.org/10.1016/j.cpa.2008.09.010

Buller, P. F., \& McEvoy, G. M. (2012). Strategy, human resource management and performance: Sharpening line of sight. Human Resource Management Review, 22(1), 43-56. http://dx.doi.org/10.1016/j.hrmr.2011.11.002

Büyüközkan, G., \& Berkol, Ç. (2011). Designing a sustainable supply chain using an integrated analytic network process and goal programming approach in quality function deployment. Expert Systems with Applications, 38(11), 13731-13748. http://dx.doi.org/10.1016/j.eswa.2011.04.171

Byrd, T. A., \& Turner, D. E. (2001). An exploratory examination of the relationship between flexible IT infrastructure and competitive advantage. Information \& Management, 39(1), 41-52. http://dx.doi.org/10.1016/S0378-7206(01)00078-7

Calabrese, A., Costa, R., \& Menichini, T. (2013). Using Fuzzy AHP to manage Intellectual Capital assets: An application to the ICT service industry. Expert Systems with Applications. http://dx.doi.org/10.1016/j.eswa.2012.12.081

Ceasar, N., \& Page, N. (2013). A time and place for sustainability. Journal of management development, 32(3), 368-276. http://dx.doi.org/10.1108/02621711311318300

Chang, L.-Y., \& Liu, W. (2009). Temple fairs in Taiwan: Environmental strategies and competitive advantage for cultural tourism. Tourism Management, 30, 900-904. http://dx.doi.org/10.1016/j.tourman.2008.12.002

Chen, L., \& Fong, P. S. W. (2012). Revealing performance heterogeneity through knowledge management maturity evaluation: A capability-based approach. Expert Systems with Applications, 39(18), 13523-13539. http://dx.doi.org/10.1016/j.eswa.2012.07.005

Chen, T.-Y., \& Chen, Y.-M. (2009). Advanced multi-phase trust evaluation model for collaboration between coworkers in dynamic virtual project teams. Expert Systems with Applications, 36(8), 11172-11185. http://dx.doi.org/10.1016/j.eswa.2009.02.090

Chuang, S.-H. (2004). A resource-based perspective on knowledge management capability and competitive advantage: an empirical investigation. Expert Systems with Applications, 27, 459-465. http://dx.doi.org/10.1016/j.eswa.2004.05.008

Chun, M., \& Mooney, J. (2009). CIO roles and responsibilities: Twenty-five years of evolution and change. Information \& Management, 46(6), 323-334. http://dx.doi.org/10.1016/j.im.2009.05.005

Dai, O., \& Liu, X. (2009). Returnee entrepreneurs and firm performance in Chinese high-technology industries. International Business Review, 18(4), 373-386. http://dx.doi.org/10.1016/j.ibusrev.2009.03.004

Dawson, A. (2012). Human capital in family businesses: Focusing on the individual level. Journal of Family Business Strategy, 3(1), 3-11. http://dx.doi.org/10.1016/j.jfbs.2011.12.001

Dehning, B., \& Stratopoulos, T. (2003). Determinants of a sustainable competitive advantage due to an IT-enabled strategy. Journal of Strategic Information Systems, 12, 7-28. http://dx.doi.org/10.1016/S0963-8687(02)00035-5

Erickson, G. S., \& Rothberg, H. N. (2009). Intellectual capital in business-to-business markets. Industrial Marketing Management, 38(2), 159-165. http://dx.doi.org/10.1016/j.indmarman.2008.12.001

Farneti, F., \& Guthrie, J. (2009). Sustainability reporting by Australian public sector organisations: Why they report. Accounting Forum, 33, 89-98. http://dx.doi.org/10.1016/j.accfor.2011.06.004

Festing, M., \& Eidems, J. (2011). A process perspective on transnational HRM systems-A dynamic capability-based analysis. Human Resource Management Review, 21(3), 162-173. http://dx.doi.org/10.1016/j.hrmr.2011.02.002

Flint, D. J., \& Golicic, S. L. (2009). Searching for competitive advantage through sustainability: A qualitative study in the New Zealand wine industry. International Journal of Physical Distribution \& LogisticsManagement, 39(10), 841-860. http://dx.doi.org/10.1108/09600030911011441 
Ganter, A., \& Hecker, A. (2013). Deciphering antecedents of organizational innovation. Journal of Business Research. http://dx.doi.org/10.1016/j.jbusres.2012.02.040

Garay, L., \& Font, X. (2012). Doing good to do well? Corporate social responsibility reasons, practices and impacts in small and medium accommodation enterprises. International Journal of Hospitality Management, 31(2), 329-337. http://dx.doi.org/10.1016/j.ijhm.2011.04.013

Garnåsjordet, P. A., Aslaksen, I., Giampietro, M., Funtowicz, S., \& Ericson, T. (2012). Sustainable development indicators: From statistics to policy. Environmental Policy and Governance, 22(5), 322-336. http://dx.doi.org/10.1002/eet.1597

Gebauer, H. (2011). Exploring the contribution of management innovation to the evolution of dynamic $\begin{array}{llll}\text { capabilities. Industrial Marketing } & \text { Management, }\end{array}$ http://dx.doi.org/10.1016/j.indmarman.2011.10.003

Griffiths, G. H., \& Finlay, P. N. (2004). IS-enabled sustainable competitive advantage in financial services, retailing and manufacturing. Journal of Strategic Information Systems, 13, 29-59. http://dx.doi.org/10.1016/j.jsis.2004.03.002

Guest, R. (2010). The economics of sustainability in the context of climate change: An overview. Journal of World Business, 45(4), 326-335. http://dx.doi.org/10.1016/j.jwb.2009.08.008

Guneri, A. F., Yucel, A., \& Ayyildiz, G. (2009). An integrated fuzzy-lp approach for a supplier selection problem in supply chain management. Expert Systems with Applications, 36(5), 9223-9228. http://dx.doi.org/10.1016/j.eswa.2008.12.021

Gupta, S., Czinkota, M., \& Melewar, T. C. (2013). Embedding knowledge and value of a brand into sustainability for differentiation. Journal of World Business. http://dx.doi.org/10.1016/j.jwb.2012.07.013

Henderson, S. (2011). The development of competitive advantage through sustainable event management. Worldwide Hospitality and Tourism Themes, 3(3), 245-257. http://dx.doi.org/10.1108/17554211111142202

Heracleous, L., \& Wirtz, J. (2009). Strategy and organization at Singapore Airlines: Achieving sustainable advantage through dual strategy. Journal of Air Transport Management, 15(6), 274-279. http://dx.doi.org/10.1016/j.jairtraman.2008.11.011

Hoots, M. (2005). Customer relationship management for facility managers. Journal of Facilities Management, 3(4), 346-361. http://dx.doi.org/10.1108/14725960510630524

Huang, C.-C., Fan, Y.-N., Chern, C.-C., \& Yen, P.-H. (2013). Measurement of analytical knowledge-based corporate memory and its application. Decision Support Systems, 54(2), 846-857. http://dx.doi.org/10.1016/j.dss.2012.09.010

Islam, S. M. N., \& Clarke, M. F. (2005). The welfare economics of measuring sustainability: A new approach based on social choice theory and systems analysis. Sustainable Development, 13(5), 282-296. http://dx.doi.org/10.1002/sd.254

Javalgi, R. G., Dixit, A., \& Scherer, R. F. (2009). Outsourcing to emerging markets: Theoretical perspectives and policy implications. Journal of International Management, 15(2), 156-168. http://dx.doi.org/10.1016/j.intman.2008.08.001

Kohtamäki, M., Partanen, J., \& Möller, K. (2013). Making a profit with R\&D services-The critical role of relational capital. Industrial Marketing Management, $42(1), \quad 71-81$. http://dx.doi.org/10.1016/j.indmarman.2012.11.001

Kuckertz, A., \& Wagner, M. (2010). The influence of sustainability orientation on entrepreneurial intentions - Investigating the role of business experience. Journal of Business Venturing, 25(5), 524-539. http://dx.doi.org/10.1016/j.jbusvent.2009.09.001

Lambert, D. M. (2010). Customer relationship management as a business process. Journal of Business \& Industrial Marketing, 25(1), 4-17. http://dx.doi.org/ 10.1108/08858621011009119

Lee, A. H. I. (2009). A fuzzy supplier selection model with the consideration of benefits, opportunities, costs and risks. Expert Systems with Applications, 36(2), 2879-2893. http://dx.doi.org/10.1016/j.eswa.2008.01.045

Lee, S. K. J., \& Yu, K. (2004). Corporate culture and organizational performance. Journal of Managerial Psychology, 19(4), 340-359. http://dx.doi.org/10.1108/02683940410537927

Lew, Y. K., \& Sinkovics, R. R. (2012). Crossing borders and industry sectors: Behavioral governance in strategic 
alliances and aroduct innovation for competitive advantage. Long Range Planning, 46(1-2), 13-38. http://dx.doi.org/10.1016/j.lrp.2012.09.006

Li, D.-Y., \& Liu, J. (2013). Dynamic capabilities, environmental dynamism, and competitive advantage: Evidence from China. Journal of Business Research. http://dx.doi.org/10.1016/j.jbusres.2012.08.007

Li, S.-T., \& Tsai, M.-H. (2009). A dynamic taxonomy for managing knowledge assets. Technovation, 29(4), 284-298. http://dx.doi.org/10.1016/j.technovation.2008.10.002

Lin, B.-W., \& Wu, C.-H. (2010). How does knowledge depth moderate the performance of internal and external $\begin{array}{llll}\text { knowledge } \quad \text { sourcing } & \text { strategies? }\end{array}$ http://dx.doi.org/10.1016/j.technovation.2010.07.001

Lu, W.-M., Wang, W.-K., Tung, W.-T., \& Lin, F. (2010). Capability and efficiency of intellectual capital: The case of fabless companies in Taiwan. Expert Systems with Applications, 37(1), 546-555. http://dx.doi.org/10.1016/j.eswa.2009.05.031

Lund, D. B. (2003). Organizational culture and job satisfaction. Journal of Business \& Industrial Marketing, 18(3), 219-236. http://dx.doi.org/10.1108/0885862031047313

Mariadoss, B. J., Tansuhaj, P. S., \& Mouri, N. (2011). Marketing capabilities and innovation-based strategies for environmental sustainability: An exploratory investigation of B2B firms. Industrial Marketing Management, 40(8), 1305-1318. http://dx.doi.org/10.1016/j.indmarman.2011.10.006

Masli, A., Richardson, V. J., Sanchez, J. M., \& Smith, R. E. (2011). Returns to IT excellence: Evidence from financial performance around information technology excellence awards. International Journal of Accounting Information Systems, 12(3), 189-205. http://dx.doi.org/10.1016/j.accinf.2010.10.001

Matzler, K., \& Mueller, J. (2011). Antecedents of knowledge sharing-Examining the influence of learning and performance orientation. Journal of Economic Psychology, 32(3), 317-329. http://dx.doi.org/10.1016/j.joep.2010.12.006

Mohrman, S. A., \& Worley, C. G. (2010). The organizational sustainability journey: Introduction to the special issue. Organizational Dynamics, 39(4), 289-294. http://dx.doi.org/10.1016/j.orgdyn.2010.07.008

Montazemi, A. Z., Pittaway, J. J., Saremi, H. Q., \& Wei, Y. (2012). Factors of stickiness in transfers of know-how between MNC units. Journal of Strategic Information Systems, 21(1), 31-57. http://dx.doi.org/10.1016/j.jsis.2012.01.001.

Morabito, V., Themistocleous, M., \& Serrano, A. (2009). A survey on integrated IS and competitive advantage. Journal of Enterprise Information, 23(2), 201-214. http://dx.doi.org/10.1108/17410391011019778

$\mathrm{Mu}$, J., Peng, G., \& MacLachlan, D. L. (2009). Effect of risk management strategy on NPD performance. Technovation, 29(3), 170-180. http://dx.doi.org/10.1016/j.technovation.2008.07.006

Munyon, T. P., Summers, J. K., \& Ferris, G. R. (2011). Team staffing modes in organizations: Strategic considerations on individual and cluster hiring approaches. Human Resource Management Review, 21(3), 228-242. http://dx.doi.org/10.1016/j.hrmr.2010.07.002

Ngai, E. W. T., Chau, D. C. K., \& Chan, T. L. A. (2011). Information technology, operational, and management competencies for supply chain agility: Findings from case studies. Journal of Strategic Information Systems, 20(3), 232-249. http://dx.doi.org/10.1016/j.jsis.2010.11.002

Nyaga, G. N., Whipple, J. M., \& Lynch, D. F. (2010). Examining supply chain relationships: Do buyer and supplier perspectives on collaborative relationships differ? Journal of Operations Management, 28(2), 101-114. http://dx.doi.org/10.1016/j.jom.2009.07.005

Passemard, D., \& Kleiner, B. H. (2000). Competitive advantage in global industries. Management Research News, 23(7/8), 111-117. http://dx.doi.org/10.1108/01409170010782307

Perry, P., \& Towers, N. (2009). Determining the antecedents for a strategy of corporate social responsibility by small- and medium-sized enterprises in the UK fashion apparel industry. Journal of Retailing and Consumer Services, 16(5), 377-385. http://dx.doi.org/10.1016/j.jretconser.2009.05.003

Phan, D. D., \& Vogel, D. R. (2010). A model of customer relationshipmanagement and business intelligence systems for catalogue and online retailers. Information \& Management, 47(2), 69-77. http://dx.doi.org/10.1016/j.im.2009.09.001

Powell, T. H., \& Ambrosini, V. (2012). A pluralistic approach to knowledge management practices: Evidence 
from consultancy companies. Long Range Planning, 45(2-3), $209-226$. http://dx.doi.org/10.1016/j.lrp.2012.02.005

Reed, R., Lemak, D. J., \& Mero, N. P. (2000). Total quality management and sustainable competitive advantage. Journal of Quality Management, 5, 5-26. http://dx.doi.org/10.1016/S1084-8568(00)00010-9

Rios-Morales, R., \& Brennan, L. (2009). Ireland's innovative governmental policies promoting internationalisation. Research in International Business and Finance, 23(2), 157-168. http://dx.doi.org/10.1016/j.ribaf.2008.03.012

Rodriguez, M. A., Ricart, J. E., \& Sanchez, P. (2002). Sustainable Development and the Sustainability of Competitive Advantage: A Dynamic and Sustainable View of the Firm. Sustainable Development and Competitive Advantage, 11(3), 135-146. http://dx.doi.org/http://dx.doi.org/10.1111/1467-8691.00246

Salunke, S., Weerawardena, J., \& McColl-Kennedy, J. R. (2011). Towards a model of dynamic capabilities in innovation-based competitive strategy: Insights from project-oriented service firms. Industrial Marketing Management, 40(8), 1251-1263. http://dx.doi.org/10.1016/j.indmarman.2011.10.009

Salunke, S., Weerawardena, J., \& McColl-Kennedy, J. R. (2013). Competing through service innovation: The role of bricolage and entrepreneurship in project-oriented firms. Journal of Business Research. http://dx.doi.org/10.1016/j.jbusres.2012.03.005

Santos-Vijande, M. L., Río-Lanza, A. B., Suárez-Álvarez, L., \& Díaz-Martín, A. M. (2013). The brand management system and service firm competitiveness. Journal of Business Research, 66(2), $148-157$. http://dx.doi.org/10.1016/j.jbusres.2012.07.007

Sharma, S., \& Ruud, A. (2003). On the path to sustainability: Integrating social dimensions into the research and practice of environmental management. Business Strategy and the Environment, 12(5), $205-214$. http://dx.doi.org/10.1002/bse.366

Tan, J., Shao, Y., \& Li, W. (2013). To be different, or to be the same? An exploratory study of isomorphism in the cluster. Journal of Business Venturing, 28(1), 83-97. http://dx.doi.org/10.1016/j.jbusvent.2012.02.003

Tollin, K., \& Jones, R. (2007). Marketing logics for competitive advantage. European Journal of Marketing, 43(3/4), 523-550. http://dx.doi.org/10.1108/03090560910935569

Tsai, W.-H., Hsu, J.-L., Chen, C.-H., Lin, W.-R., \& Chen, S.-P. (2010). An integrated approach for selecting corporate social responsibility programs and costs evaluation in the international tourist hotel. International Journal of Hospitality Management, 29(3), 385-396. http://dx.doi.org/10.1016/j.ijhm.2009.12.001

Tseng, S.-M. (2012). Correlations between external knowledge and the knowledge chain as impacting service quality. Journal of Retailing and Consumer Services, 19(4), $429-437$. http://dx.doi.org/10.1016/j.jretconser.2012.04.004

Wagner, M. (2005). Sustainability and competitive advantage: Empirical evidence on the influence of strategic choices between environmental management approaches. Environmental Quality Management, 14(3), 31-48. http://dx.doi.org/10.1002/tqem.20046

Watjatrakul, B. (2005). Determinants of IS sourcing decisions: A comparative study of transaction cost theory versus the resource-based view. Journal of Strategic Information Systems, 14(4), 389-415. http://dx.doi.org/10.1016/j.jsis.2005.05.001

Wei, C.-C., \& Chang, H.-W. (2011). A new approach for selecting portfolio of new product development projects. Expert Systems with Applications, 38(1), 494-434. http://dx.doi.org/10.1016/j.eswa.2010.06.081

Wilkinson, A., \& Hill, M. (2001). The sustainability debate. International Journal of Operations \& Production Management, 21(12), 1492-1502. http://dx.doi.org/10.1108/01443570110410865

Wu, H.-Y., Chen, J.-K., \& Chen, I.-S. (2010). Innovation capital indicator assessment of Taiwanese Universities: A hybrid fuzzy model application. Expert Systems with Applications, 37(2), $1635-1642$. http://dx.doi.org/10.1016/j.eswa.2009.06.045

Wu, L.-Y. (2010). Applicability of the resource-based and dynamic-capability views under environmental volatility. Journal of Business Research, 63(1), 27-31. http://dx.doi.org/10.1016/j.jbusres.2009.01.007

Zheng, W., Yang, B., \& McLean, G. N. (2010). Linking organizational culture, structure, strategy, and organizational effectiveness: Mediating role of knowledge management. Journal of Business Research, 63(7), 763-771. http://dx.doi.org/10.1016/j.jbusres.2009.06.005 


\section{Copyrights}

Copyright for this article is retained by the author(s), with first publication rights granted to the journal.

This is an open-access article distributed under the terms and conditions of the Creative Commons Attribution license (http://creativecommons.org/licenses/by/3.0/). 